\section{Two ministries at war}

\section{Paris}

A PROPOSAL to squeeze defence spending in order to finance an ambitious expansion in education and research, while reducing the balance of payments deficit, has provoked an internal squabble in the French government. The proposal, believed to have come from Prime Minister Michel Rocard, has set the minister for defence, Jean-Pierre Chevènement and finance minister, Pierre Bérégovoy at logger-heads.

The problem has arisen because defence commitments undertaken in 1987 are now turning out to be too heavy in the light of the socialist government's priorities for education - a ticket that helped them win the elections last year. The defence budget growth is traditionally fixed every four years. In 1987, the annual growth rate was set at 6 per cent, with an understanding that the rate for 1990-93 would be revaluated this year. If the 6 per cent increase is continued for the next four years, as was expected, FF470,000 million ( $\$ 74,600$ million) would be available for a major overhaul of France's military capability agreed in 1987. This includes the construction of a new nuclear-powered aircraft carrier, a combat helicopter and the Rafale fighter plane. But Bérégovoy says the four-year budget cannot exceed FF400,000 million if he is to balance his books while supporting government priorities in education.

Chevènement, himself a former education minister, is adamant that the growth rate in military spending must not fall below 5 per cent up to 1993 if France's security is not to be jeopardised. Even a 4 per cent increase, which he has ruled out outright, would be FF32,000 million more than the defence minister is prepared to pay and would reduce defence spending from its current 3.69 per cent of gross domestic product (GDP) to 3.56 per cent. Education currently receives 4.5 per cent of GDP.

Michel Rocard intervened early last week, saying there is no interministerial conflict, "just normal discussions within a government during a difficult year". In a statement to the press, Rocard added that "there is no question of cutting defence spending, simply a need to discuss the rate of increase". Meanwhile, Chevènement, who is known to have a short fuse, having resigned as education minister in the previous socialist government, is looking to see where cuts can be made. He has already decided to close non-strategic air bases and is considering extending the Rafale construction deadline, even though this could damage French arms export contracts.

Peter Coles

\section{Amherst, Massachusetts}

MORE than fifty students were arrested at the University of Massachusetts last week following the occupation of a university building to protest against research supported by the US Army. The target of the protestors was microbiologist Curtis B. Thorne, who studies the anthrax bacillus with funding from the army's biological defence research programme.

As the student occupation went on, a special hearing before the local Board of Health heard testimony on a proposed ordinance to ban from the town of Amherst "the testing, storage, transportation, and disposal of biological materials if funded in full or in any part by the US Army's Biological Defence Research Program". Nearly 200 students, residents, and outside experts drawn from around the region gathered for more than three hours to debate the ordinance which would effectively outlaw Thorne's research from the town limits. A decision is not expected until wider discussion at a town meeting in May.

$\mathrm{NIH}$

\section{Wyngaarden resigns}

\section{Washington}

THE director of the US National Institutes of Health (NIH), James B. Wyngaarden, announced last week that he will not be continuing in office under the new presidential administration. His resignation will take effect on 1 August.

Although ready to move on to other things, Wyngaarden explained that it was "not so much my decision as theirs". As a Reagan appointee, he was required to offer his resignation on the change of administration. A national search committee headed by James $\mathrm{O}$. Mason, newly appointed Assistant Secretary of Health and Human Services (HHS), will be responsible for nominating potential successors.

During Wyngaarden's seven years in office, the NIH budget has doubled. He has presided over a huge increase in backing for AIDS research and fought successfully to retain control of the human genome project at the NIH. He says that one of his priorities has been to improve the productivity and stability of research. During his tenure, the proportion of five-year awards has risen from 20 to more than 50 per cent.

Wyngaarden has not always toed the White House line. He did not endorse the ban on research using human fetal tissue imposed by the Assistant Secretary for Health last July and he has said publicly that he feels abortion is a matter of private choice. He was not asked about his stance on abortion at his confirmation hearings, but the same may not be true for his successor.
University of Massachusetts chancellor Joseph Duffy fought back with a written statement at the meeting vowing to "protect the right of our faculty to conduct any research they choose as long as the scope, methods and results can be fully and freely disclosed", adding that the policy would not be negotiated with students.

Support for the student protests came from several researchers, including Richard P. Novick, molecular biologist and director of the Public Health Research Institute in New York. He said that Thorne's research presented a health threat to the community and "could not be construed as for peaceful purposes".

Thorne denies that his five-year, $\$ 600,000$ research contract poses a safety hazard. He says that the issue of safety is not the protesters' real concern, and that his research is being used merely as a tactic to force a debate on "the larger issue" of "whether it's moral or immoral" to accept funding from the military - a debate Thorne says he will not participate in.

\section{Seth Shulman}

\section{US ACADEMY}

\section{Welcome to the club}

\section{Washington}

THE US National Academy of Sciences held its 126th annual meeting in Washington last week, where it held symposia, listened to speeches and elected 60 new members. Membership is "one of the highest honours that can be accorded a US scientist or engineer", the academy says. But who has the best chance of being elected by their peers? According to statistics compiled by the academy's own news and public information office, the successful candidate will most likely come from

Academy membership April 1988

University

No. of

Harvard Univ

Massachusetts inst. Technology members

Stanford Univ

110

Univ. California, Berkeley

California Inst. Technology

Yale Univ.

Univ. California, San Diego

Univ. Chicago

Univ. Wisconsin, Madison

Princeton Univ.

Harvard, have won a Nobel prize in physiology or medicine, and be male.

As of last year's elections, 1,486 of the 1,539 (96.6 per cent) living members of the academy were men. Since 1863 when the Academy was established there have been only 65 female members.

One hundred and forty-eight academy members have won Nobel prizes; 111 before they were elected, 29 after, and 6 the same year.

Joseph Palca 